\title{
On the Normative and Legal Basis of the System of Social Protection in Uzbekistan
}

\author{
Parizod Boyqobilova \\ Senior Lecturer Department of Philosophy and National Idea Tashkent State Technological University
}

\begin{abstract}
BSTRACT: The article deals with the normative and legal basis of comprehensive reforms and changes in the social protection system in Uzbekistan. It provides feedback on the reforms in the sector, as well as strategic goals for further development of the social protection system in the future. In this context, it is important for the state to properly organize social support for the population, especially low-income and large families, based on local conditions, the national mentality of the people, the way of life.
\end{abstract}

EY WORDS: Social protection, law, decision, decree, population, low-income families, pensions, mothers and children, wages, benefits, income, support, system, social support, population, national mentality, local conditions.

\section{NTRODUCTION}

Family The essence of the concept of social protection is that the state provides protection and assistance to needy families, the disabled, orphans, the bereaved, children and low-income families. In this context, it is important for the state to properly organize social support for the population, especially low-income and large families, based on local conditions, the national mentality of the people, the way of life. It is no coincidence that after gaining its independence, Uzbekistan, unlike other countries, has firmly developed a strong social policy.

\section{Methods}

The article is based on the methods of objectivity, consistency, historical and comparative analysis, chronological study of historical and social events, reliance on sources and evidence and their authenticity. It studied the regulatory framework of the comprehensive reforms and changes in the system of social protection in Uzbekistan, the consistent social policy pursued by Uzbekistan during the years of independence on the basis of objective criteria.

\section{ESEARCH RESULTS}

According to the national model of social assistance in Uzbekistan, the following types of benefits and privileges will be provided, along with the retention of lump-sum payments for the birth of a child. For example, the amount of benefits paid to nursing mothers has not only been increased, but also extended. Since 1991, such assistance has been paid for up to one and a half years, but since 1994 this period has been extended to two years. Both working mothers and non-working mothers have benefited from this pension.

One of the most important legal reforms in this area was the adoption on August 28, 1994 of the Resolution of the Cabinet of Ministers of the Republic of Uzbekistan "On the organization of social protection of low-income families". On the basis of this decision, the Regulation "On the procedure for registration, appointment and payment of financial assistance to low-income families" was adopted [1.1994]. On the basis of these normative and legal acts, the Republican Public Charitable Foundation "District" and its regional structures have provided financial assistance to needy and low-income families, lonely 
elderly and disabled people.

For example, in 1995, 3\% of the funds allocated for social protection were allocated to mothers for the care of their children under two years of age [2. 228]. This system was formed in connection with the minimum amount of pensions and salaries in the republic. This primarily served to ensure the indexation of this type of benefits in the face of increased depreciation of money. In particular, instead of more than twenty different child benefits, a single benefit was introduced in September 1994 for all families with children. In this regard, in $1995,51 \%$ of the funds allocated for social protection were allocated to families to care for their children until they reach the age of two.

Of course, one of the most vulnerable segments of the population is low-income families. If we look to the recent past, their funding by the state has been constantly improved. In this regard, in accordance with the Resolution of the Cabinet of Ministers of the Republic of Uzbekistan dated December 10, 1996 № 437 "On measures to strengthen social support for families with children" minors (with children under 16 , as well as for families with children aged 16 to 18 studying in academic lyceums and professional colleges) benefits were appointed and paid by the citizens' self-government bodies. The Presidential Decree of November 20, 1995 "On strengthening the state social assistance to families with children" played an important role in providing financial assistance to vulnerable groups. According to it, from April 1, 1996, benefits for families with children under the age of 16 began to be paid to all families, regardless of the amount of income of the parents and the family as a whole. In other words, children under the age of 16 were given direct state assistance regardless of various factors and causes [3.1995].

Part of the government's expenditures on child care and upbringing was reimbursed to families, while parental responsibility was strengthened. The maximum amount of pension for a family with five or more children was originally set at half the minimum wage, and by 1996 at the level of the full rate of the minimum wage.

At the initial stage of the reforms, the measures taken in Uzbekistan became of great social significance at a time when the majority of the population in many countries of the former Soviet Union was impoverished. This has strengthened people's confidence to accelerate reforms [4.225].

In this regard, in accordance with the Decree of the President of the Republic of Uzbekistan dated January 13, 1999 'On increasing the role of citizens' selfgovernment bodies in providing targeted social assistance to the population", as of March 1, 1999, in addition to the existing measures for social support of the population, non-working mothers through the mahalla self-government bodies, the appointment and payment of childcare allowances until the child reaches the age of 2 years, the provision of basic foodstuffs to single pensioners in need of care of others [5. 1995. 14.01]. Unlike other sectors, it can be seen that a large part of the total state budget is directed to the social sphere.

According to the Law on the State Budget, adopted in 2006, 39103.6 million soums were allocated to citizens' self-government bodies in 2007 and 56730.2 million soums in 2008. These numbers have grown in recent years as well. For example, in 2014 alone, salaries, pensions and stipends increased by $23.2 \%$, and real incomes increased by $10.2 \%$ [6.63. ]. In particular, in the last five years until 2016, 1 billion 976.8 million soums were allocated to support needy families in the country, 1 billion 272 million soums to restore the health of 6838 people, 1 billion 501 million soums to repair the homes of 2336 people [ 7. №3. 29]. The results in the social sphere in the period up to 2015, in particular, the increase in public spending on social protection of the population by more than 5 times, are certainly a positive result.

For example, in 1998, local self-government bodies provided financial assistance to 700,000 people in the country, or $11.8 \%$ of the total number of families. The amount of financial assistance provided to each family amounted to more than 1,730 soums per month. On this basis, in 1998, 36\% of families with children received benefits. The average pension per family was almost 1,483 soums, or five times (compared to 1996). During this period, the amount of monthly financial assistance increased from 600 soums to 8186 soums, or 13.6 times [8.46].

As a result of the election of Shavkat Mirziyoyev as President of Uzbekistan in 2016, the country has entered a new era of rapid renewal and reform in all areas. In this regard, the improvement of the financial situation of the population in need of social protection, the creation of many conditions for the resolution of their appeals, and the transition to a new stage of reform.

In particular, over the years, practical steps have been taken to identify and address shortcomings in this area. In this regard, the "People's Reception" and "Virtual Reception" of the President of the Republic of Uzbekistan played an important role. In order to actively communicate with the public, to further improve the system of dealing with appeals of individuals and legal entities, introduced in 2017, "Mobile receptions" were organized in cities and villages of the country.

In particular, until April 1, 2018, representatives of the Republican "Working Group on Public Oversight" under the Cabinet of Ministers visited the regions of the country to study the social situation in the districts, many problems were solved on the spot by conducting mobile raids to address the complaints of the 
population and to the "People's Reception" [9.2018]. This system plays an important role in solving social problems today.

In this regard, President Shavkat Mirziyoyev said in his Address to the Oliy Majlis on December 28, 2018, "Economic development and social protection are interrelated concepts and cannot be imagined in isolation. In particular, in 2019 - the "Year of Active Investment and Social Development" for the further development of the social sphere it is necessary to perform the following tasks." To do this, it is necessary to implement the following strategic tasks, the President said [10. 2018. 29. 01].

First, it is necessary to reduce unemployment among the population, increase the income of people and families. The government is expected to approve a new state employment promotion program for 2019 within a month. In this regard, it is necessary to provide vocational training to the unemployed, provide them with legal and other advice, as well as other social assistance methods. To improve the living standards of our people, we need to form a decent wage system and increase real incomes. According to it, it is planned to revise the procedure for setting the minimum wage, eliminate the link between taxes and other payments to the minimum wage, and instruct the Cabinet of Ministers to develop a package of measures to address this issue within two months.

Second, it is necessary to reconsider the procedure for assigning and paying pensions and benefits, to radically reform the pension system. Indeed, according to the newly adopted Presidential Decree, from January 1, 2019, all working retirees will be paid pensions in full. After all, according to the new system of social protection, a new system is being introduced to increase the maximum wage from 8 to 10 times the minimum wage for the calculation of pensions. In the next phase of the reforms, these restrictions will also be completely abolished. At the same time, the issue of social protection of children with disabilities and their families, those who have lost their breadwinners until the age of sixteen should always be in the center of our attention. We will introduce a special type of social benefits for mothers who have dedicated their lives to caring for a disabled child, the President said. [11. 2018. 29. 01].

In recent years, in order to increase the welfare of citizens, to improve their lifestyle, the idea that "the people should serve the people, not government agencies" is being implemented. Further increasing the effectiveness of reforms, creating all conditions for a good life, modernization of the country and liberalization of all spheres of life are reflected in the Action Strategy for the five priority areas of further development of the Republic of Uzbekistan in 20172021.

\section{Conclusion}

In conclusion, during the years of independence, increase the real income and purchasing power of the population, further reduce the number of low-income families and the level of income inequality, we have witnessed the promulgation of many laws and decrees, Presidential decrees on the gradual increase of salaries, pensions, stipends and social benefits of public sector employees above inflation, which are aimed at the social protection of the people.

Especially in today's renewed Uzbekistan, in accordance with the Action Strategy for the five priority areas of further development of the Republic of Uzbekistan for 2017-2021, the state, along with social support for the needy, creates favorable conditions for those seeking to ensure the welfare of their families. That is, the introduction of the program "Every family is an entrepreneur", preferential loans for entrepreneurship, housing for the disabled, orphans, the bereaved and the needy on a preferential basis, the provision of land plots, temporary and excessive inspections and tax exemptions for producers are helping to ensure social stability in Uzbekistan today.

\section{EFERENCES}

1. Resolution of the Cabinet of Ministers of the Republic of Uzbekistan "On the organization of social protection of low-income families." // Level of legislation of the Republic of Uzbekistan. 1994.

2. New history of Uzbekistan. // The third book. History of independent Uzbekistan. Tashkent; 2000. P. 228.

3. Decree of the President of the Republic of Uzbekistan "On strengthening state social assistance to families with children" // Collection of legislation of the Republic of Uzbekistan. Tashkent:, 1995.

4. New history of Uzbekistan. // The third book. History of independent Uzbekistan. Tashkent:, 2000. P. 225.

5. Decree of the President of the Republic of Uzbekistan "On increasing the role of citizens' selfgovernment bodies in providing targeted social assistance to the population." "People's word"., January 14, 1999.

6. Karimov I. A. Serving for the happiness and great future of our motherland is the highest happiness. Tashkent:, "Uzbekistan”.2015. P. 63.

7. Inog'omov J. Mahalla-Institute of Social Protection // Civil Society. 2016 №3. P. 29.

8. Ashirmatov $\mathrm{H}$. Issues of social protection of citizens in Uzbekistan. A dissertation written for a master's degree. T., 2009. P. 46.

9. January, February, March issues of the republican newspaper "Mahalla". Tashkent:, 2018

10. Address of the President of the Republic of Uzbekistan Shavkat Mirziyoyev to the Oliy Majlis. 
People's Word newspaper. Tashkent:. December 29, 2018.

11. Address of the President of the Republic of Uzbekistan Shavkat Mirziyoyev to the Oliy Majlis. People's Word newspaper. Tashkent:. December 29, 2018.

12 zodbek, N., Tolipov, F., \& Yunusova, X. (2019). Historical and ethnographic features of the Uzbek Kurash. International Journal of Recent Technology and Engineering, 8(2 Special Issue 3), 1614-1616. 